\title{
Reversal of Chloroquine and Mefloquine Resistance in Plasmodium falciparum by the Two Monoindole Alkaloids, Icajine and Isoretuline
}

Michel Frédérich ${ }^{1,2}$, Monique Tits ${ }^{1}$, Marie-Pierre Hayette ${ }^{2}$, Patrick De $\mathrm{Mol}^{2}$, Luc Angenot ${ }^{1}$

'Laboratoire de Pharmacognosie, Institut de Pharmacie, Université de Liège, BELGIUM.

${ }^{2}$ Laboratoire de Microbiologie Médicale, Institut de Pathologie, Université de Liège,

$$
\text { BELGIUM. }
$$

The chloroquine-potentiating activities of the Strychnos myrtoides alkaloids strychnobrasiline and malagashanine has been demonstrated in vitro and in vivo by Rasoanaivo et al. in 1994 [1]. In the continuation of our search for new antiplasmodial indole alkaloids [2] and with the aim of finding new resistance-modifiers agents, eight naturally occurring monoindole alkaloids (icajine, strychnobrasiline, isoretuline, retuline, vomicine, novacine, holstiine and dolichantoside) were evaluated in vitro for their ability to inhibit Plasmodium falciparum growth and, in drug combination, to reverse the resistance of a chloroquine-resistant strain of Plasmodium falciparum. None of these indole alkaloids has significant intrinsic antiplasmodial activity $\left(\mathrm{IC}_{50}>10 \mu \mathrm{M}\right.$ or $5 \mu \mathrm{g} / \mathrm{ml}$ ). Nevertheless, three alkaloids (icajine, isoretuline and strychnobrasiline) reverse chloroquine resistance at concentrations between 2.5 and $25 \mu \mathrm{g} / \mathrm{ml}$ (IF of 12.82 for isoretuline on W2 strain). The Interaction Factor (IF) equals $2,<2$, or $>2$ for additive, antagonistic or synergistic effects of alkaloids on chloroquine inhibition, respectively. Icajine and isoretuline were also assessed in vitro for their mefloquine potentiating activity on a mefloquine-resistant strain of Plasmodium falciparum. Only icajine proved to be synergistic with mefloquine (IF $=15.38)$.

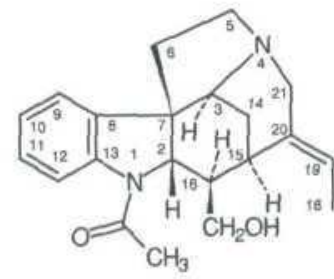

Isoretuline

Retuline: $\mathrm{H}-16 \beta$

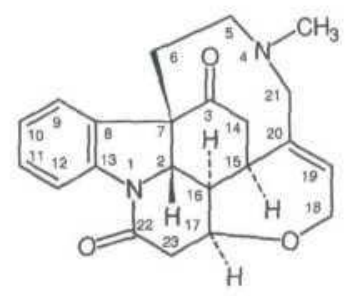

Icajine

This work was supported by the National Fund for Scientific Research of Belgium (Grant number 3.4519.01) whose M.F. is Postdoctoral Researcher.

[1] Rasoanaivo P, Ratsimamanga-Urverg S, Milijaona R, Rafatro H, Rakoto-Ratsimamanga A, Galeffi C, Nicoletti M., Planta Medica 1994, 60: 13-6.

[2] Frédérich M, De Pauw-Gillet MC, Llabres G, Tits M, Hayette MP, Brandt V, Penelle J, De Mol P, Angenot L., Planta Medica 2000, 66: 262-9. 